\title{
一次元シミュレーションによる定在波型熱音響冷凍機の数值解析
}

\author{
入江 凛*1，岩本 壮太郎 ${ }^{* 2}$ ，垣田 健 ${ }^{* 3}$, 田中 誠一 ${ }^{* 4}$, 藤原 誠之*4
}

\section{Numerical analysis of a standing-wave thermoacoustic refrigerator by one-dimensional simulation}

\author{
Rin IRIE ${ }^{* 1}$, Sotaro IWAMOTO ${ }^{* 2}$, Ken KAKITA ${ }^{* 3}$, Seiichi TANAKA ${ }^{* 4}$ and Seiji FUJIWARA ${ }^{* 4}$ \\ ${ }^{* 1}$ Department of Mechanical Engineering, National Institute of Technology, Akashi College \\ (Current affiliation: Nippon Telegraph and Telephone Corporation \\ 3-9-11 Midori-cho, Musashino-shi, Tokyo 180-8585, Japan) \\ ${ }^{* 2}$ Department of Mechanical Engineering, National Institute of Technology, Akashi College \\ (Current affiliation: Department of Mechanical Engineering, The University of Tokyo \\ 7-3-1 Hongo, Bunkyo-ku, Tokyo 113-8656, Japan) \\ ${ }^{* 3}$ Department of Mechanical Engineering, National Institute of Technology, Akashi College \\ (Current affiliation: Department of Mechanical Science and Bioengineering, Osaka University \\ 1-3 Machikaneyama-cho, Toyonaka-shi, Osaka 560-8531, Japan) \\ ${ }^{* 4}$ Department of Mechanical Engineering, National Institute of Technology, Akashi College \\ 679-3 Nishioka, Uozumi-cho, Akashi-shi, Hyogo 674-8501, Japan
}

Received: 19 June 2018; Revised: 24 October 2018; Accepted: 10 December 2018

\begin{abstract}
In this paper, a numerical simulation for a standing-wave thermoacoustic refrigerator using the equations of conservation law are proposed. In this simulation, the gas flow in the thermoacoustic refrigerator is expressed by the quasi onedimensional model to reduce the computational load. Since the equations of conservation law are solved directly in the simulation in contrast to the conventional analysis applying the thermoacoustic theory, our simulation is excellent in adaptability and extensibility and can be used for developing actual machines. The equations of continuity, motion, energy and the state of the gas were solved utilizing a TVD scheme for the spatial difference and Heun's method for the time difference. The numerical simulations were performed on ten types of thermoacoustic refrigerators having regenerators of different thermophysical properties and hydraulic diameters, and the simulation results were compared with the corresponding experimental results. As for the results, a heat pump effect, or thermoacoustic refrigerating effect, was observed successfully by means of our simulation. The highest thermoacoustic refrigerating effect was obtained when a product $\omega \tau$ of angular frequency of sound wave $\omega$ and thermal relaxation time $\tau$ was around 5, and the result agreed well with the previous research. Furthermore, the simulation results of thermoacoustic refrigerating effect for the different types of refrigerators were consistent with experimental results within an error of $10 \%$. These results verify the validity of our proposed simulation method.
\end{abstract}

Keywords : Thermoacoustic refrigerator, Standing-wave type, CFD, Quasi-1D model

\section{1. 緒言}

熱音響現象とは熱と仕事の相互変換を表す。一般的に自由空間を伝播する断熱音波では熱交換は生じないが，波 長に比べてある程度細い管内を伝播する音波は，管壁との間の熱交換を通じて様々な現象を引き起こす。例えば，

No.18-00268 [DOI:10.1299/transjsme.18-00268], J-STAGE Advance Publication date : 20 December, 2018

*1 明石工業高等専門学校 機械工学科（現 日本電信電話(株）（干180-8585 東京都武蔵野市緑町 3-9-11)）

*2 明石工業高等専門学校 機械工学科（現 東京大学大学院工学系研究科機械工学専攻（干113-8656 東京都文京区本郷 7-3-1））

*3 明石工業高等専門学校 機械工学科(現 大阪大学大学院基礎工学研究科機能創成専攻 ( 5 560-8531 大阪府豊中市待兼山町 1-3))

${ }^{* 4}$ 正員, 明石工業高等専門学校 機械工学科（广674-8501 兵庫県明石市魚住町西岡 679-3)

E-mail of corresponding author: rin.irie.nf@hco.ntt.co.jp 


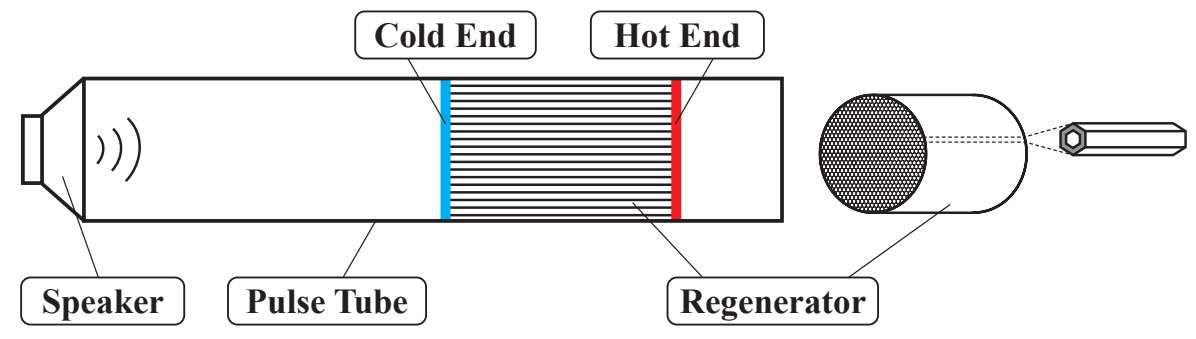

Fig. 1 Schema of a standing-wave thermoacoustic refrigerator.

管の軸方向に急激な温度勾配を与えることで，管内の気体は平均気圧の $10 \%$ を超える大振動が発生し (Rayleigh, 1896)，その逆現象である，音波から温度勾配を発生させるヒートポンプ効果の存在も理論的に示されている (Merkli and Thomann, 1975).

音波から温度勾配が生じる熱音響現象を利用した冷凍機を，熱音響冷凍機と呼ぶ。定在波型熱音響冷凍機は最 もシンプルな構造であり, 図 1 に示すように片側が閉端の管の中に蓄熱体を挿入し, 他端にスピーカーなどの音 波を発生させる装置を配置した構造を持つ。蓄熱体はセラミックスなどの熱容量の大きな材料に，多数の矩形や 六角形などの孔が管にあいているものである，スピーカーから管の共鳴周波数の音波を入力すると, 気柱共鳴に よって定在波が生じる。この定在波によって蓄熱体内の気体は軸方向に振動し，膨張と収縮に伴う気体の温度変 化が発生し，蓄熱体との間で熱交換が行われる。ここで, 蓄熱体と気体との熱緩和時間を適切に設定することで, 受熱場所と放熱場所がずれて，バケッリレーのように気体粒子によって熱が輸送される．従来の冷凍機にはピス トンなどの可動部が存在するが，熱音響冷凍機は音波を発生させるスピーカー以外に可動部を持たないため，耐 久性，整備性に優れている。またフロンガスなどの環境負荷の高い冷媒を必要としないため，環境負荷の少ない 冷凍機としても注目を集めている (矢崎他, 2006).

定在波型熱音響冷凍機は，1963 年に Gifford らによって開発されたものを始まりに (Gifford and Longsworth, 1964), 現在までにいくつも改良版が提案されている (西谷, 2000)。熱音響冷凍機は冷媒を使用しないため，動作温度に依 存せず $30 \mathrm{~K}$ を下回る温度に到達できることや，環境負荷が低いことも相まって，冷凍機の性能改善に関する研究 は多く存在する (Mikulin et al., 1984, Zhu et al., 1990)。熱音響冷凍機の動作原理は, 熱音響理論により説明できる が (富永, 1990), 熱音響理論を用いるには適切な温度場が必要となることから, 性能改善に向けた開発は実験と の対応が不可欠である，熱音響理論以外で動作原理を理解する方法として，流路壁面との熱交換を考慮した圧縮 性流体の支配方程式を数值的に解き，その結果から得られる速度場や圧力場，温度場を解析する方法が効果的で あると言われている (小清水他, 2002)。この方法に基づく先行研究では，共鳴管内の作動流体の運動を二次元あ るいは三次元の円筒座標系としてモデル化したものがほとんどである (De Jong et al., 2013, El-Rahman et al., 2012, El-Rahman and Abdel-Rahman, 2013, Jaensch et al., 2017, 小清水他, 2002, Skaria et al., 2015, Sun et al., 2016). しか し冷凍機の性能予測のために数值計算を行う場合, 性能に関連する変数を広い範囲で探索する必要があり, 従って 計算負荷は可能な限り小さいほうが好ましい.

定在波型熱音響冷凍機に対する一次元モデルでの数值計算を行った先行研究はいくつか存在するが (El-Rahman and Abdel-Rahman, 2014, Han et al., 2012, Holzinger et al., 2015)，実際の装置を用いた実験結果と比較し，計算モデ ルの有効性を議論しているものは我々の知るところでは存在しない，そこで本論文では，定在波型熱音響冷凍機内 の作動流体を準一次元流孔と近似したモデルを提案する．さらに定在波型熱音響冷凍機の性能を支配する無次元 量 $\omega \tau$ （作動流体の振動角周波数 $\omega$, 流体と蓄熱体との熱緩和時間 $\tau$ ) と蓄熱体流路の断面開口率 $R_{\mathrm{OFA}}$ に対して, 数值シミュレーションの結果と実機での測定結果を比較し, 提案するモデルによる性能評価の有効性を検証する.

\section{2. 数値計算モデル}

\section{$2 \cdot 1$ 熱音響冷凍機の準一次元モデル}

熱音響冷凍機の蓄熱体による流路の断面積変化を考慮して，軸方向の流体運動を準一次元でモデル化したもの の概略図を図 2 に示す。ただし, 共鳴管全長を $L_{\mathrm{p}}$, 流路直径を $D_{\mathrm{p}}$, 流路断面積 $S_{\mathrm{p}}$, 流路周長 $l_{\mathrm{p}}$ とする. また蓄 熱体全長を $L_{\mathrm{r}}$, 流路水力直径を $D_{\mathrm{r}}$, 蓄熱体挿入位置をスピーカーからの距離 $x_{\mathrm{r}}$ とする。蓄熱体は, 作動流体の流 路となる共鳴管直径より小さい流路が複数あり, その流路断面積 $S_{\mathrm{r}}$ にっって断面開口率 $R_{\mathrm{OFA}}\left(=S_{\mathrm{r}} / S_{\mathrm{p}}\right)$ が定まる. このモデルでは, 蓄熱体流路の水力直径 $D_{\mathrm{r}}$ は 1 本分の流路に相当するが, 流路周長 $l_{\mathrm{r}}$ や流路断面積 $S_{\mathrm{r}}$ は全流路を 


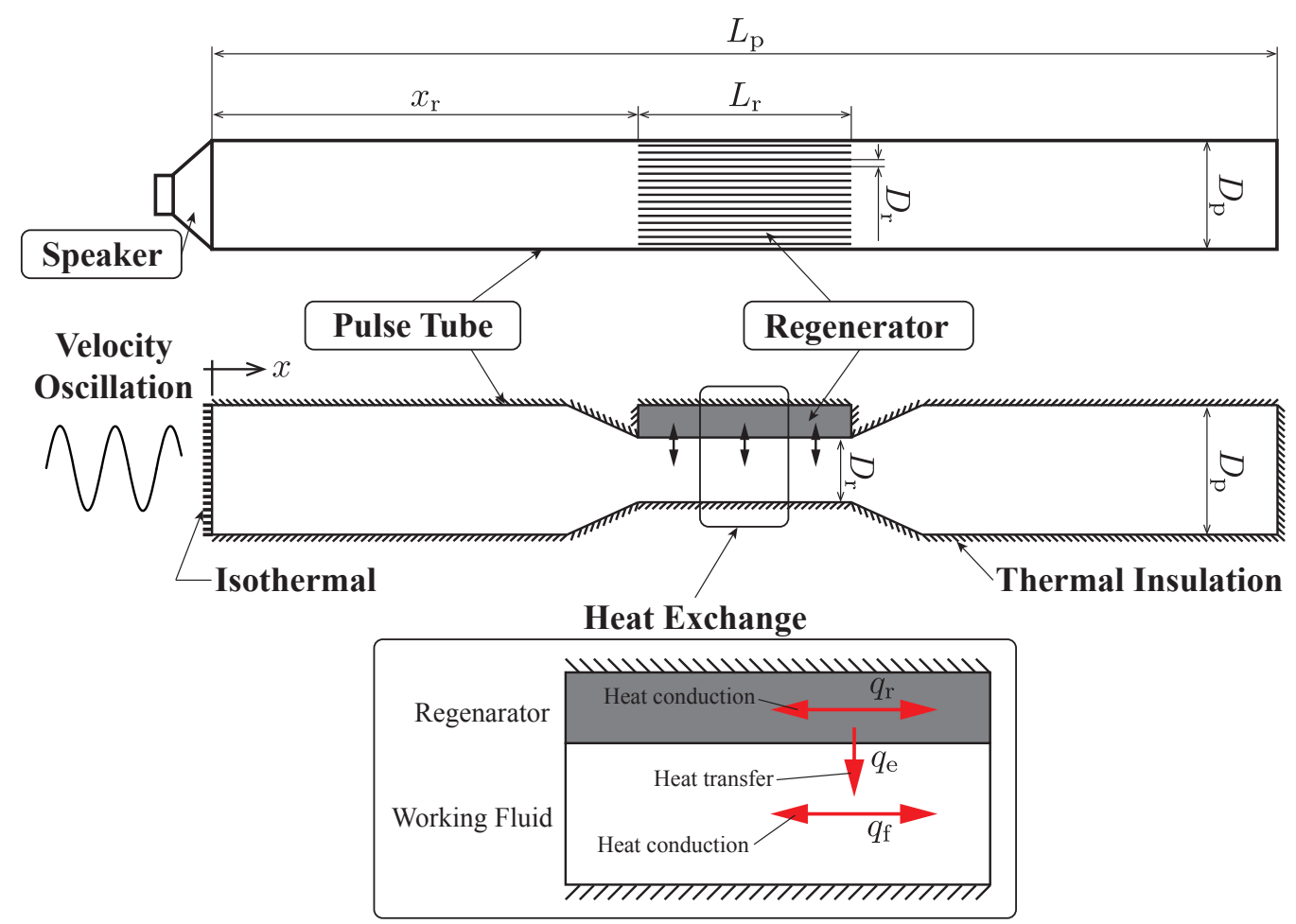

Fig. 2 Quasi one-dimensional model of the thermoacoustic refrigerator.

合計したものとすることで，蓄熱体と作動流体との接触面積や共鳴管の断面開口率の整合性を取っている，共鳴 管内に発生する振動流は，共鳴管左端の境界条件として作動流体の流速を周期的に変動させることで与える。ま た共鳴管の外壁は左端の境界を除き断熱とし, 蓄熱体と作動流体との熱交換以外の熱の流入出は生じないとする. 作動流体の初期温度 $T_{0}$, 初期圧力 $p_{0}$ の分布は一様とする.

蓄熱体と作動流体との熱交換は動径方向で行われ，両者の温度差によって熱移動 $q_{\mathrm{e}}$ が発生する。ここで，蓄熱 体と作動流体との熱伝達率は，管内の作動流体の状態に依存し，一意に定まらない．そこで本論文では，蓄熱体 の壁面温度が周期変動する際の流体との熱交換を熱伝導のみで支配されると仮定して，解析したヌッセルト数 $N u$ を周期平均して適用する簡易モデルを用いる (藤原他, 2012). 熱音響冷凍機では，蓄熱体の温度勾配が大きくなる につれて熱伝導による熱移動も大きくなり，その熱輸送量とヒートポンプ効果による熱輸送量とが釣り合うこと で定常状態になるため, 蓄熱体の熱伝導は熱音響冷凍機の到達温度に大きく関係すると考えられている. 従って, 作動流体と蓄熱体の動軸方向で熱伝導による熱移動 $q_{\mathrm{f}}, q_{\mathrm{r}}$ を考慮する.

\section{$2 \cdot 2$ 基礎方程式}

熱音響冷凍機の作動流体は理想流体で, 圧縮性の一次元流孔とする。また，蓄熱体の出入口で断面積変化の影響 を考慮するために，運動量の項に断面積の空間勾配による湧き出し項を加えた (渡辺他, 1995)。時間 $t$, 空間 $x$ に おける作動流体の密度 $\rho(t, x)$, 流速 $u(t, x)$, 圧力 $p(t, x)$, 内部エネルギ $\varepsilon(t, x)$, 流路断面積 $S(x)$ とするとき, その 基礎方程式は

$$
\begin{aligned}
& \frac{\partial(S \boldsymbol{U})}{\partial t}+\frac{\partial(S \boldsymbol{F})}{\partial x}=S \boldsymbol{E}+\boldsymbol{H}, \\
& \boldsymbol{U}=\left[\begin{array}{l}
\rho \\
m \\
e
\end{array}\right], \quad \boldsymbol{F}=\left[\begin{array}{c}
m \\
m^{2} / \rho+p \\
m(e+p) / \rho
\end{array}\right], \quad \boldsymbol{E}=\left[\begin{array}{l}
0 \\
0 \\
Q
\end{array}\right], \quad \boldsymbol{H}=\left[\begin{array}{c}
0 \\
p \cdot \partial S / \partial x \\
0
\end{array}\right]
\end{aligned}
$$


となる. ただし， $m=\rho u, e=\left(\varepsilon+1 / 2 u^{2}\right)$ とする. 作動流体に出入りする単位体積あたりの熱量 $Q$ は, 熱伝導に よる熱移動 $q_{\mathrm{f}}$ と蓄熱体との熱伝達による熱移動 $q_{\mathrm{e}}$ を用いて, $Q=q_{\mathrm{f}}+q_{\mathrm{e}}$ と表現される。ここで各熱移動量は,

$$
q_{\mathrm{f}}=\kappa_{\mathrm{f}} \frac{\partial^{2} T_{\mathrm{f}}}{\partial x^{2}}, \quad q_{\mathrm{e}}= \begin{cases}h \frac{l_{\mathrm{r}}}{S_{\mathrm{r}}}\left(T_{\mathrm{r}}-T_{\mathrm{f}}\right) & \left(x_{\mathrm{r}} \leq x \leq x_{\mathrm{r}}+L_{\mathrm{r}}\right), \\ 0 & (\text { otherwise })\end{cases}
$$

である．ただし，作動流体温度 $T_{\mathrm{f}}(t, x)$ は，比熱比 $\gamma ，$ ガス定数 $R$ とするとき，状態方程式より $T_{\mathrm{f}}=\varepsilon(\gamma-1) / R$ で表 される。 また作動流体の熱伝導率 $\kappa_{\mathrm{f}}$, 熱伝達率 $h$, 蓄熱体温度 $T_{\mathrm{r}}(t, x)$, 蓄熱体全流路周長 $l_{\mathrm{r}}$ である. 熱伝達率 $h$ は, 平均ヌッセルト数 $\overline{N u}=8.0+0.07 \cdot(2 \omega \tau)^{0.8}$ を用いて, $h=\overline{N u} \cdot \kappa_{\mathrm{f}} / D_{\mathrm{r}}$ とする (藤原他, 2012)。ここで, 作動流体の 振動角周波数 $\omega$, 作動流体の熱拡散率 $\alpha_{\mathrm{f}}, \tau$ は流体が管壁と熱平衡に達するまでの緩和時間であり $\tau=D_{\mathrm{r}}^{2} /\left(2 \alpha_{\mathrm{f}}\right)$ と表される。

最後に蓄熱体の熱伝導方程式は，作動流体との熱伝達による熱移動 $q_{\mathrm{e}}$ を考慮して，

$$
\frac{\partial T_{\mathrm{r}}}{\partial t}=\frac{1}{\rho_{\mathrm{r}} c_{\mathrm{r}}}\left(\kappa_{\mathrm{r}} \frac{\partial^{2} T_{\mathrm{r}}}{\partial x^{2}}-q_{\mathrm{e}}\right)
$$

となる，ただし，蓄熱体の熱伝導率 $\kappa_{\mathrm{r}}$, 密度 $\rho_{\mathrm{r}}$, 比熱 $c_{\mathrm{r}}$ であり，左辺は $q_{\mathrm{r}}$ を意味する.

\section{$2 \cdot 3$ 計算スキーム}

断面積 $S$ は時間 $t$ に依存しないため, 式(1)は以下のように式変形できる：

$$
\frac{\partial \boldsymbol{U}}{\partial t}=-\frac{1}{S} \frac{\partial(S \boldsymbol{F})}{\partial x}+\boldsymbol{E}+\frac{\boldsymbol{H}}{S} .
$$

従って式 (5)を, 空間離散化した上で時間離散化をすることで, 計算スキームを導出する. 数値振動を抑えるため には，全変動が時間とともに増加しないという条件（TVD; Total Variation Diminishing）を満たす必要があるとい われており (Harten, 1984)，本論文では，TVD 条件を満たす Harten-Yee の風上型差分法 (Yee, 1987) を参考に空 間離散化を行う。また時間離散化には，空間離散化と同じ 2 次精度の Heun 法を用いる。ここで， $j=\{0, \ldots, k\}$, $n=\{0, \ldots, N\}$ とするとき, ある変数 $z(t, x)$ の時刻 $t=n \Delta t$, 位置 $x=j \Delta x$ における近似值を $z_{(j)}^{(n)}$ と表し, 各変数は この規則に準ずるとする．式(5)に対する計算スキームは以下に示すとおりである：

$$
\begin{aligned}
& \boldsymbol{U}_{(j)}^{(n+1)}=\boldsymbol{U}_{(j)}^{(n)}+\frac{\Delta t}{2}\left\{\boldsymbol{C}_{1}+\boldsymbol{C}_{2}\right\}, \\
& \boldsymbol{C}_{1}=-\frac{1}{S_{(j)}} \frac{S_{\left(j+\frac{1}{2}\right)} \tilde{\boldsymbol{F}}_{\left(j+\frac{1}{2}\right)}^{(n)}-S_{\left(j-\frac{1}{2}\right)} \tilde{\boldsymbol{F}}_{\left(j-\frac{1}{2}\right)}^{(n)}+\boldsymbol{E}_{(j)}^{(n)}+\frac{\boldsymbol{H}_{(j)}^{(n)}}{S_{(j)}},}{\Delta x} \boldsymbol{C}_{2}=-\frac{1}{S_{(j)}} \frac{S_{\left(j+\frac{1}{2}\right)} \tilde{\boldsymbol{F}}_{\left(j+\frac{1}{2}\right)}^{\left(n^{\prime}\right)}-S_{\left(j-\frac{1}{2}\right)} \tilde{\boldsymbol{F}}_{\left(j-\frac{1}{2}\right)}^{\left(n^{\prime}\right)}+\boldsymbol{E}_{(j)}^{\left(n^{\prime}\right)}+\frac{\boldsymbol{H}_{(j)}^{\left(n^{\prime}\right)}}{\Delta x},}{S_{(j)}^{(n)}} \\
& \boldsymbol{U}_{(j)}^{(n)}=\left[\boldsymbol{\rho}_{(j)}^{(n)}, m_{(j)}^{(n)}, e_{(j)}^{(n)}\right]^{\top}, \boldsymbol{E}_{(j)}^{(n)}=\left[0,0, Q_{(j)}^{(n)}\right]^{\top}, \boldsymbol{H}_{(j)}^{(n)}=\left[0,\left(p_{(j+1)}^{(n)}+p_{(j-1)}^{(n)}\right)\left(S_{\left(j+\frac{1}{2}\right)}-S_{\left(j-\frac{1}{2}\right)}\right) /(2 \cdot \Delta x), 0\right]^{\top} .
\end{aligned}
$$

ただし $\tilde{\boldsymbol{F}}^{\left(n^{\prime}\right)}, \boldsymbol{E}^{\left(n^{\prime}\right)}, \boldsymbol{H}^{\left(n^{\prime}\right)}$ は, $\boldsymbol{U}^{\left(n^{\prime}\right)}=\boldsymbol{U}_{(j)}^{(n)}+\Delta t \cdot \boldsymbol{C}_{1}$ によって導かれる值である.ここで数值流速 $\tilde{\boldsymbol{F}}_{\left(j+\frac{1}{2}\right)}^{(n)}$ は以下で 定義される：

$$
\tilde{\boldsymbol{F}}_{\left(j+\frac{1}{2}\right)}^{(n)}=\frac{1}{2}\left\{\left(\boldsymbol{F}_{(j+1)}^{(n)}+\boldsymbol{F}_{(j)}^{(n)}\right)+R_{\left(j+\frac{1}{2}\right)}^{(n)} \Phi_{\left(j+\frac{1}{2}\right)}^{(n)}\right\} .
$$

ただし $\boldsymbol{F}_{(j)}^{(n)}$ は $\boldsymbol{F}$ の時刻 $t=n \Delta t$, 位置 $x=j \Delta x$ における近似值

$$
\boldsymbol{F}_{(j)}^{(n)}=\left[m_{(j)}^{(n)},\left(m_{(j)}^{(n)}\right)^{2} / \rho_{(j)}^{(n)}+p_{(j)}^{(n)}, m_{(j)}^{(n)}\left(e_{(j)}^{(n)}+p_{(j)}^{(n)}\right) / \rho\right]^{\top}
$$

である.ここで流速ヤコビアン行列 $A\left(A_{i j}:=\partial \boldsymbol{F}_{i} / \partial \boldsymbol{U}_{j}\right)$ の右固有值 $\lambda$ に対応する右固有ベクトルを順に束ねた行 列を $R$ とするとべクトル $\Phi$ の各成分は

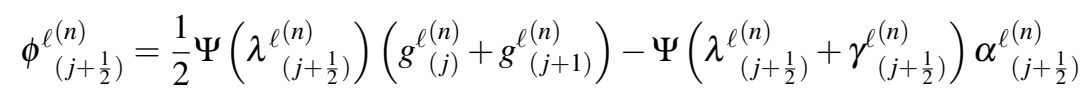


である．ただし上添字 $\ell$ はベクトルの各成分のインデックスであり，特性波を意味する．ここで $\gamma_{\left(j+\frac{1}{2}\right)}^{(n)}$ は，

$$
\begin{aligned}
& \gamma_{\left(j+\frac{1}{2}\right)}^{\ell^{(n)}}= \begin{cases}\frac{1}{2} \Psi\left(\lambda_{\left(j+\frac{1}{2}\right)}^{\ell^{(n)}}\right)\left(g_{(j+1)}^{\ell^{(n)}}-g_{(j)}^{\ell_{(n)}^{(n)}}\right) / \alpha^{\ell}{ }_{\left(j+\frac{1}{2}\right)} & \left(\alpha^{\ell}{ }_{\left(j+\frac{1}{2}\right)} \neq 0\right), \\
0 & \left(\alpha^{\ell}{ }_{\left(j+\frac{1}{2}\right)}=0\right),\end{cases} \\
& g_{(j)}^{\ell_{(j)}^{(n)}}=\operatorname{minmod}\left(\alpha_{\left(j+\frac{1}{2}\right)}^{\ell^{(n)}}, \alpha_{\left(j-\frac{1}{2}\right)}^{\ell^{(n)}}\right)
\end{aligned}
$$

であり (Kermani and Plett, 2001)，またベクトル $\boldsymbol{\alpha}$ は

$$
\boldsymbol{\alpha}_{\left(j+\frac{1}{2}\right)}^{(n)}=R_{\left(j+\frac{1}{2}\right)}^{-1(n)}\left(\boldsymbol{U}_{(j+1)}^{(n)}+\boldsymbol{U}_{(j)}^{(n)}\right) .
$$

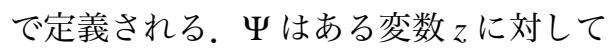

$$
\Psi(z)= \begin{cases}|z| & (|z| \geq \delta), \\ \left(z^{2}+\delta^{2}\right) /(2 \delta) & (|z|<\delta)\end{cases}
$$

である.ただし，エントロピ補正係数 $\delta$ は人工粘性と関係しており，数值解の収束性に影響を与えると言われて いる (村上, 藤原, 2000). 予備計算において, $\delta$ が 0.001 以下で数值解が一定值に収束することが確認できたため, 以下では $\delta=0.001$ とする.

次に作動流体に出入りする熱量 $Q_{(j)}^{(n)}$ は,

$$
\begin{aligned}
& Q_{(j)}^{(n)}=q_{\mathrm{f}}^{(n)}+(j) \\
& q_{\mathrm{e}}(n) \\
& \mathrm{f}_{(j)}^{(n)}=\kappa_{\mathrm{f}} \frac{\left(T_{\mathrm{f}(j+1)}-T_{\mathrm{f}(j)}\right) S_{(j)}-\left(T_{\mathrm{f}(j)}-T_{\mathrm{f}(j-1)}\right) S_{(j-1)}}{\Delta x \cdot V_{(j)}}, \\
& q_{\mathrm{e}_{(j)}}^{(n)}= \begin{cases}h_{l_{\mathrm{f}}}\left(T_{\mathrm{r}_{(j)}}^{(n)}-T_{\mathrm{f}_{(j)}}^{(n)}\right) & \left(k_{1} \leq j \leq k_{2}\right), \\
0 & \text { (otherwise) }\end{cases}
\end{aligned}
$$

である.ここで作動流体温度 $T_{\mathrm{f}(j)}^{(n)}$ は,

$$
T_{\mathrm{f}}^{(n)}(j)=\varepsilon_{(j)}^{(n)} \frac{\gamma-1}{R}
$$

と表される。また， $k_{1}, k_{2}$ は蓄熱体両端の格子位置であり， $k_{1}=x_{\mathrm{r}} / \Delta x, k_{2}=\left(x_{\mathrm{r}}+L_{\mathrm{r}}\right) / \Delta x$ である。ただし流路断 面積 $S_{\left(j+\frac{1}{2}\right)}$ 及び格子あたりの体積 $V_{(j)}$ は以下で定義される：

$$
\begin{aligned}
& V_{(j)}=\frac{\Delta x}{3}\left(S_{(j)}+S_{(j-1)}+\sqrt{S_{(j)} S_{(j-1)}}\right), \\
& S_{\left(j+\frac{1}{2}\right)}=\frac{1}{2}\left(S_{(j)}+S_{(j-1)}\right) .
\end{aligned}
$$

蓄熱体の熱伝導方程式については，式 (4)をまずは空間方向に有限差分法で離散化した後に，時間方向は Heun 法によって離散化を行う：

$$
\begin{aligned}
& T_{\mathrm{r}}^{(n+j)}(n+1)=T_{\mathrm{r}_{(j)}^{(n)}}^{(n)}+\frac{\Delta t}{2}\left\{C_{1}+C_{2}\right\},
\end{aligned}
$$

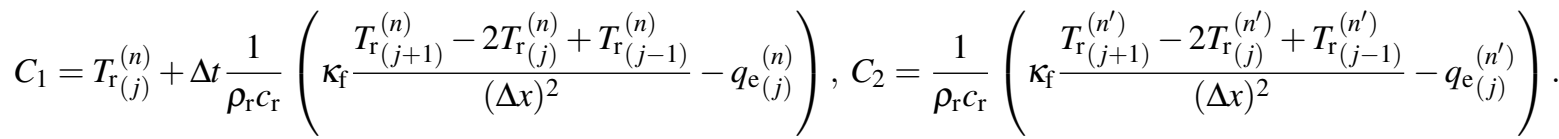

ただし $q_{\mathrm{e}}^{\left(n^{\prime}\right)}$ は, $T_{\mathrm{r}}^{\left(n^{\prime}\right)}=T_{\mathrm{r}(j)}^{(n)}+\Delta t \cdot C_{1}$ と $\boldsymbol{U}^{\left(n^{\prime}\right)}$ によって導かれる值である. 


\section{4 初期条件・境界条件}

初期条件は $0 \leq j \leq k$ において,

$$
u_{(j)}^{(0)}=0, \quad \rho_{(j)}^{(0)}=\rho_{0}, \quad p_{(j)}^{(0)}=p_{0}, \quad T_{\mathrm{r}(j)}^{(0)}=T_{\mathrm{f}(j)}^{(0)}
$$

とする. ただし初期圧力 $p_{0}$, 初期密度 $\rho_{0}, k:=L_{\mathrm{p}} / \Delta x$ である. また流路断面積 $S_{(j)}$ は, $0 \leq j \leq k$ について次のよ うに定義する：

$$
S_{(j)}=\left\{\begin{array}{ll}
S_{\mathrm{r}} & \left(k_{1}-1 \leq j \leq k_{2}\right) \\
S_{\mathrm{p}} & (\text { otherwise })
\end{array} .\right.
$$

次に作動流体の境界条件について述べる，共鳴管左端にスピーカーによって入力される音波は，左端（ $j=0 ）$ の 流速を正弦波で周期的に時間変化させることで表現する。 また共鳴管左端では等温条件とし，従って境界条件は，

$$
u_{(0)}^{(n)}=u_{\mathrm{amp}} \sin (\omega \cdot n \Delta t), \quad \rho_{(0)}^{(n)}=\rho_{0}, \quad p_{(0)}^{(n)}=p_{0}
$$

となる．ただし， $u_{\mathrm{amp}}$ は入力音波の振幅である．また，共鳴管右端は閉端かつ断熱であるため，境界条件は次の ように定める：

$$
u_{(k-1)}^{(n)}=u_{(k+1)}^{(n)}, \quad \rho_{(k-1)}^{(n)}=\rho_{(k+1)}^{(n)}, \quad p_{(k-1)}^{(n)}=p_{(k+1)}^{(n)} .
$$

最後に蓄熱体の境界条件は，両端に熱交換器を用いないものとし，断熱とした：

$$
T_{\mathrm{r}_{\left(k_{1}-1\right)}^{(n)}}^{(n)}=T_{\mathrm{r}\left(k_{1}\right)}^{(n)}, \quad T_{\mathrm{r}\left(k_{2}+1\right)}^{(n)}=T_{\mathrm{r}_{\left(k_{2}\right)}^{(n)}}^{(n)} .
$$

\section{3. 数值シミュレーション}

\section{$3 \cdot 1$ 計算条件}

表 1 に，計算モデルおよびスキームの変数と物性値を示す。ただし作動流体は標準状態の空気とし，参考值 (日 本熱物性学会, 2008) を用いた。熱音響冷凍機の寸法などの変数は, 後に示す実験結果と比較するため, 実際の装置 に合わせて設定している．また詳細は第 3.3 節にて後述するが， $v_{\mathrm{amp}}$ は実験結果と比較するための推定値である.

蓄熱体はセラミックス（コーディライト）製の外径 $0.05 \mathrm{~m}$, 全長 $0.1 \mathrm{~m}$ で，気孔率や水力直径，流路断面積な どが異なる 10 種類のものを用いる。それぞれの形状，物性值を表 2 に示す。ただしセラミックスは複合材料であ り，七ラミックス内に空気が存在している気孔体であるため，気孔率 $n$ に応じて物性值はそれぞれ異なる。蓄熱 体を微粒子分散型複合材料とした際の密度 $\rho_{\mathrm{r}}$, 比熱 $c_{\mathrm{r}}$, 熱伝導率 $\kappa_{\mathrm{r}}$, 熱拡散率 $\alpha_{\mathrm{r}}$ は以下で定まる (日本熱物性学 会, 2008)：

$$
\begin{aligned}
\rho_{\mathrm{r}} & =n \cdot \rho_{\mathrm{a}}+(n-1) \cdot \rho_{\mathrm{s}}, \\
c_{\mathrm{r}} & =\frac{n \cdot c_{\mathrm{a}} \rho_{\mathrm{a}}+(n-1) \cdot c_{\mathrm{s}} \rho_{\mathrm{s}}}{n \cdot \rho_{\mathrm{a}}+(n-1) \cdot \rho_{\mathrm{s}}}, \\
\kappa_{\mathrm{r}} & =\frac{\left(\kappa_{\mathrm{s}}+\kappa_{\mathrm{a}}\right)-n \cdot\left(\kappa_{\mathrm{s}}-\kappa_{\mathrm{a}}\right)}{\left(\kappa_{\mathrm{s}}+\kappa_{\mathrm{a}}\right)+n \cdot\left(\kappa_{\mathrm{s}}-\kappa_{\mathrm{a}}\right)} \kappa_{\mathrm{s}}, \\
\alpha_{\mathrm{r}} & =\frac{\kappa_{\mathrm{r}}}{c_{\mathrm{r}} \cdot \rho_{\mathrm{r}}} .
\end{aligned}
$$

ただし, 空気の物性值は表 1 と同様に密度 $\rho_{\mathrm{a}}=\rho_{0}$, 比熱 $c_{\mathrm{a}}=c_{\mathrm{f}}$, 熱伝導率 $\kappa_{\mathrm{a}}=\kappa_{\mathrm{f}}$ である. セラミックスは, 密 度 $\rho_{\mathrm{s}}=2650 \mathrm{~kg} / \mathrm{m}^{3}$, 比熱 $c_{\mathrm{s}}=730.0 \mathrm{~J} / \mathrm{kg} \cdot \mathrm{K}$, 熱伝導率 $\kappa_{\mathrm{s}}=3.0 \mathrm{~W} / \mathrm{m} \cdot \mathrm{K}$ とする (日本熱物性学会, 2008).

\section{$3 \cdot 2$ シミュレーション結果}

表 1 , 表 2 に示す変数に基づいてシミュレーションを行つた結果について考察する. ただし本節で計算に用いる 蓄熱体は，熱拡散率 $\alpha_{r}$ が中央值を取るサンプル Aのみである.

初めに動作開始から 5 周期までの挙動について解析する. 図 3 に動作開始から 5 周期目までの共鳴管左端 $(x=0.01$ $\mathrm{m} ）$ における作動流体の圧力 $p_{(1)}$ と流速 $u_{(1)}$ の経時変化を，図 4 に動作開始から 5 周期目における 1 周期の圧力空 
Table 1 Calculation conditions.

\begin{tabular}{|c|c|c|}
\hline \multicolumn{3}{|l|}{ SHAPE OF THE REFRIGERATOR } \\
\hline Length of the pulse tube $L_{\mathrm{p}}$ & 1.0 & $\mathrm{~m}$ \\
\hline Stream diameter of the pulse tube $D_{\mathrm{p}}$ & 0.05 & $\mathrm{~m}$ \\
\hline Stream cross-section of the pulse tube $S_{\mathrm{p}}$ & $\pi D_{\mathrm{p}}^{2} / 4$ & $\mathrm{~m}^{2}$ \\
\hline Length of the regenerator $L_{\mathrm{r}}$ & 0.1 & $\mathrm{~m}$ \\
\hline Insert position of the regenerator $x_{\mathrm{r}}$ & 0.8 & $\mathrm{~m}$ \\
\hline \multicolumn{3}{|l|}{ WORKING FLUID (AIR) } \\
\hline Initial pressure $p_{0}$ & 101325 & $\mathrm{~Pa}$ \\
\hline Initial density $\rho_{0}$ & 1.29304 & $\mathrm{~kg} / \mathrm{m}^{3}$ \\
\hline Initial temperature $T_{0}$ & 273.15 & $\mathrm{~K}$ \\
\hline Thermal conductivity $\kappa_{\mathrm{f}}$ & 0.024 & $\mathrm{~W} / \mathrm{m} \cdot \mathrm{K}$ \\
\hline Thermal diffusivity $\alpha_{\mathrm{f}}$ & $19.39 \times 10^{-6}$ & $\mathrm{~m}^{2} / \mathrm{s}$ \\
\hline Gas constant $R$ & 287.06 & $\mathrm{~J} / \mathrm{kg} \cdot \mathrm{K}$ \\
\hline Specific heat ratio $\gamma$ & 1.4 & \\
\hline Specific heat $c_{\mathrm{f}}$ & $\gamma R /(\gamma-1)$ & $\mathrm{J} / \mathrm{kg} \cdot \mathrm{K}$ \\
\hline Speed of sound $v_{\mathrm{s}}$ & $\sqrt{\gamma p_{0} / \rho_{0}}$ & $\mathrm{~m} / \mathrm{s}$ \\
\hline \multicolumn{3}{|l|}{ PART OF THE SPEAKER } \\
\hline Frequency of the operation $f$ & $v_{\mathrm{s}} /\left(4 \cdot L_{\mathrm{p}}\right)$ & $\mathrm{Hz}$ \\
\hline Amplitude of the velocity $v_{\text {amp }}$ & 2.65 & $\mathrm{~m} / \mathrm{s}$ \\
\hline \multicolumn{3}{|l|}{ DISCRETIZATION } \\
\hline Number of the space grids $k$ & 100 & \\
\hline Number of the time steps $N_{\text {end }}$ & $3600 / \Delta t$ & \\
\hline Space grid width $\Delta x$ & $L_{\mathrm{p}} / k$ & $\mathrm{~m}$ \\
\hline Time step width $\Delta t$ & $\Delta x /\left(2 \cdot v_{\mathrm{S}}\right)$ & $\mathrm{s}$ \\
\hline
\end{tabular}

Table 2 Dimensions and thermophysical properties of regenerators.

\begin{tabular}{|c|r|r|r|r|r|r|r|r|}
\hline ID & Porosity & $\begin{array}{r}\text { Hydraulic } \\
\text { diameter }\end{array}$ & $\begin{array}{r}\text { All stream } \\
\text { cross-section }\end{array}$ & $\begin{array}{r}\text { Regenerator } \\
\text { cross-section }\end{array}$ & Density & $\begin{array}{r}\text { Specific } \\
\text { heat }\end{array}$ & $\begin{array}{r}\text { Thermal } \\
\text { conductivity } \\
\kappa_{\mathrm{r}} \mathrm{W} / \mathrm{m} \cdot \mathrm{K}\end{array}$ & $\begin{array}{r}\text { Thermal } \\
\text { diffusivity } \\
\alpha_{\mathrm{r}} \mathrm{m}^{2} / \mathrm{s}\end{array}$ \\
\hline $\mathrm{A}$ & 0.337 & 1.133 & 1540.8 & 422.7 & 1757.4 & 730.07 & 1.5057 & $1.1736 \times 10^{-6}$ \\
$\mathrm{~B}$ & 0.333 & 1.580 & 1653.1 & 310.4 & 1768.0 & 730.07 & 1.5190 & $1.1769 \times 10^{-6}$ \\
$\mathrm{C}$ & 0.261 & 0.686 & 1666.8 & 296.7 & 1958.7 & 730.05 & 1.7738 & $1.2405 \times 10^{-6}$ \\
$\mathrm{D}$ & 0.327 & 1.105 & 1496.6 & 466.9 & 1783.9 & 730.07 & 1.5392 & $1.1819 \times 10^{-6}$ \\
$\mathrm{E}$ & 0.313 & 1.182 & 1694.3 & 269.2 & 1821.0 & 730.06 & 1.5870 & $1.1938 \times 10^{-6}$ \\
$\mathrm{~F}$ & 0.337 & 1.302 & 1722.8 & 240.7 & 1757.4 & 730.07 & 1.5057 & $1.1736 \times 10^{-6}$ \\
$\mathrm{G}$ & 0.337 & 1.324 & 1599.3 & 364.2 & 1757.4 & 730.07 & 1.5057 & $1.1736 \times 10^{-6}$ \\
$\mathrm{H}$ & 0.338 & 1.170 & 1627.7 & 335.8 & 1754.7 & 730.07 & 1.5024 & $1.1727 \times 10^{-6}$ \\
$\mathrm{I}$ & 0.336 & 0.934 & 1547.6 & 415.9 & 1760.0 & 730.07 & 1.5090 & $1.1744 \times 10^{-6}$ \\
$\mathrm{~J}$ & 0.490 & 1.081 & 1478.9 & 484.6 & 1352.1 & 730.13 & 1.0480 & $1.0615 \times 10^{-6}$ \\
\hline
\end{tabular}

間分布の推移を示す. 図 3 より, 共鳴管左端にスピーカに相当するものとして与えた作動流体に対する境界条件で ある式 (23) によって, 共鳴管に圧力変動が再現されていることが確認できた。また図 4 よ，共鳴管左端 $(x=0.01$ $\mathrm{m})$ は圧力変動がない箇所 (節), 共鳴管右端 $(x=1.0 \mathrm{~m}$ ) は圧力が最も変動する箇所 (腹) が発生しており, 従つ て共鳴管内に 4 分の 1 波長の定在波が存在していることが確認できた。ただし，蓄熱体両端の流路絞り部では局 所的な圧力下降または上昇が発生しているが，これは流路断面積が変化していることが原因と考えられる。次に， $x=0.80 \mathrm{~m}$ （蓄熱体低温端）における作動流体温度 $T_{\mathrm{f}(80)}$ と $x=0.90 \mathrm{~m}$ （蓄熱体高温端）の温度 $T_{\mathrm{f}(90)}$ の経時変化を 図 5 に示す。作動流体は, 蓄熱体低温端および高温端において圧力変動に比例する温度変化が発生しており, 流 


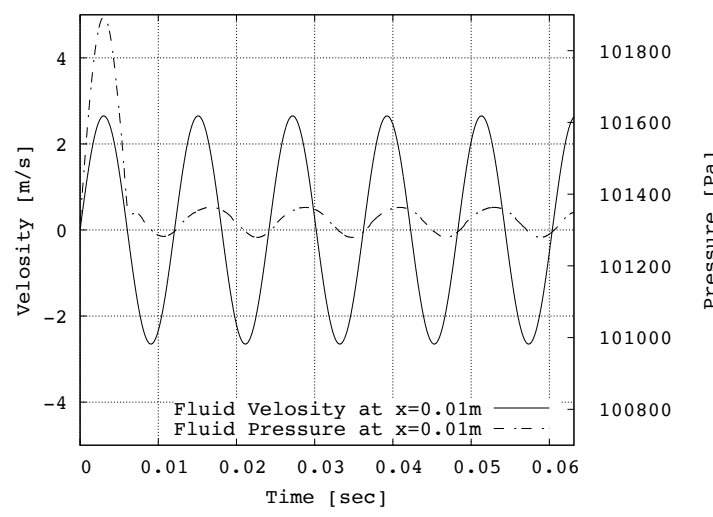

Fig. 3 Behavior of fluid velocity and pressure during initial Fig. 4 5 cycles at $x=0.01 \mathrm{~m}$ in the case of regenerator A.

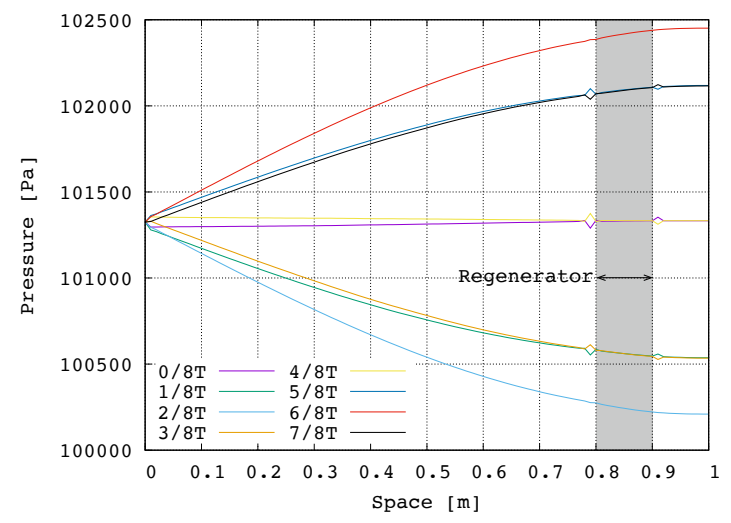

Space distribution of fluid pressure at initial 5th cycle in the case of regenerator A.

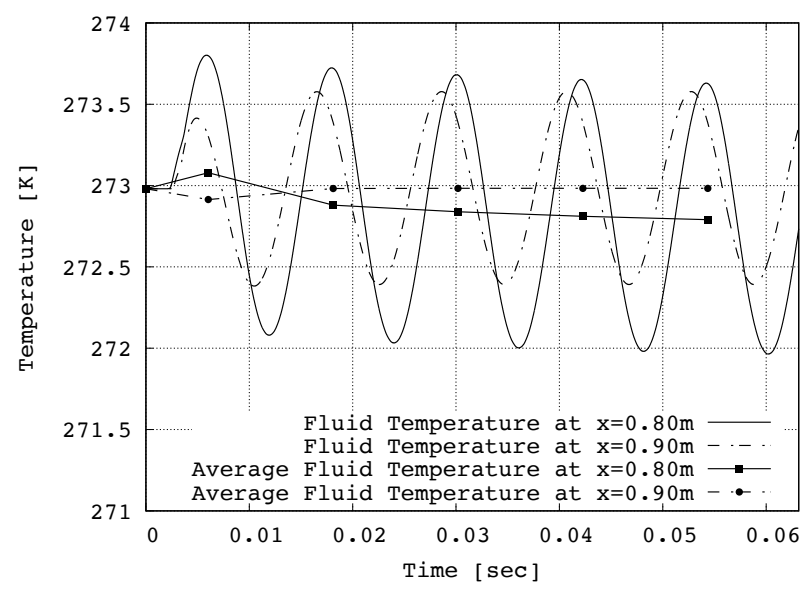

Fig. 5 Behavior of regenerator temperature at its both ends during initial 5 cycles in the case of regenerator A.

体の 1 周期平均温度から，時間とともに蓄熱体両端にある流体の温度差が大きくなっていることが確認できた。

作動流体の温度について 1 周期平均したものの空間分布を図 6 に，密度についてを図 7 に示す．ただしこれらは， 100 秒， 200 秒， 300 秒，400 秒，500 秒，750 秒，1000 秒，3600 秒における值である. 図 6 より，蓄熱体の挿入 位置において温度勾配が発生しており，時間経過とともにその両端の温度差が大きくなっている．ここで $x=0.80$ $\mathrm{m}$ (蓄熱体低温端) 近傍において，1000 秒のときよりも 3600 秒のほうが温度が高くなっている。これは共鳴管左 端では断熱の境界条件を与えていないため僅かに熱が流入し, 熱音響効果による温度低下が定常状態となった後 は，その影響によって徐々に温度が上昇したためと考えられる。また図 7 より，図 6 に示す温度分布と密度は状 態方程式の関係と整合する。

図 8 に蓄熱体低温端 $(x=0.80 \mathrm{~m})$ における蓄熱体温度 $T_{\mathrm{r}(80)}$ と高温端 $(x=0.90 \mathrm{~m})$ における温度 $T_{\mathrm{r}(90)}$ の 1 周 期平均の温度の経時変化を示す．またその両端の温度差 $\Delta T_{\mathrm{r}}\left(=T_{\mathrm{r}(90)}-T_{\mathrm{r}(80)}\right)$ についても示す． 3000 秒以降に蓄熱 体両端の温度差が一定になっていることから, 定常状態になったと判断できる.ただし蓄熱体両端の境界条件は 断熱としているが，蓄熱体両端の温度は時間とともに上昇している。これは，流体を介して蓄熱体より外側へ微 量の熱が流出して，共鳴管全体の温度が上昇していくためと考えられる.

次に蓄熱体流路水力直径 $D_{\mathrm{r}}$ を変化させた際の蓄熱体両端の温度差 $\Delta T_{\mathrm{r}}$ の挙動を解析する. ただし, 蓄熱体の断 面開口率 $R_{\mathrm{OFA}}$ は一定とし水力直径のみを変化させるため, 水力直径を減少させると蓄熱体流路本数が増加する. ここで, 作動流体の振動角周波数 $\omega$ と流体が管壁と熱平衡に達するまでの緩和時間 $\tau$ の積 $\omega \tau=\omega D_{\mathrm{r}}{ }^{2} / 2 \alpha_{\mathrm{f}}$ は, 共 鳴管内の音波伝播を支配する無次元量である (矢崎他, 2006). 図 9 に水力直径 $D_{\mathrm{r}}$ を変化させた場合の蓄熱体両端 の温度差 $\Delta T_{\mathrm{r}}$ について, 無次元量 $\omega \tau$ を用いて解析したものを示す. 図 9 より, 蓄熱体両端の温度差は $\omega \tau$ が 5 程 度のときに最も大きく, $\omega \tau \sim 5$ から離れるにつれて $\Delta T_{\mathrm{r}}$ は小さくなる. 定在波型熱音響冷凍機では, $\omega \tau$ が 1 か ら 10 程度において最も効率よくヒートポンプ効果が得れるといわれており (上田他, 2001), この数值計算の結果 


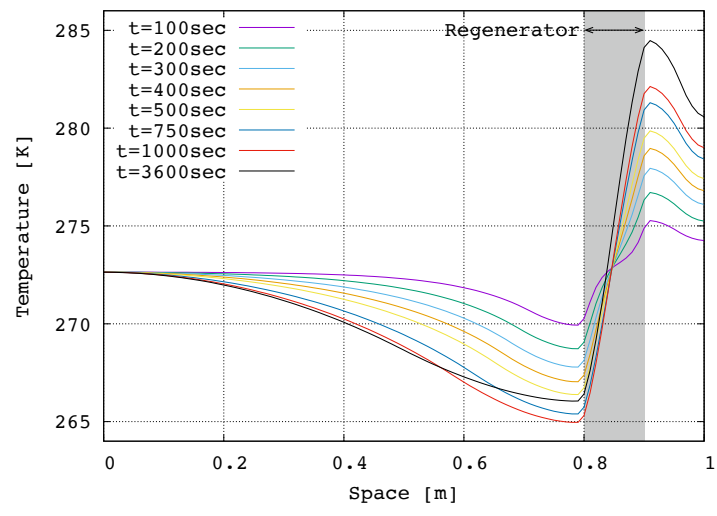

Fig. 6 Space distribution of fluid temperature until steady Fig. 7 state in the case of regenerator $\mathrm{A}$.

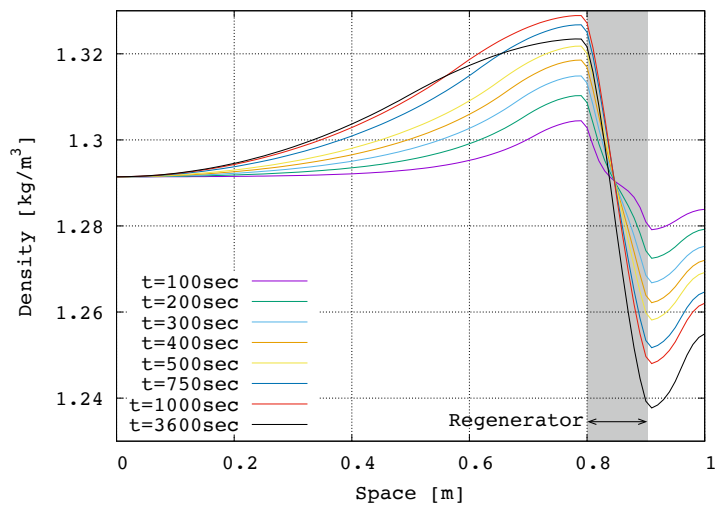

Space distribution of fluid density until steady state in the case of regenerator $\mathrm{A}$.

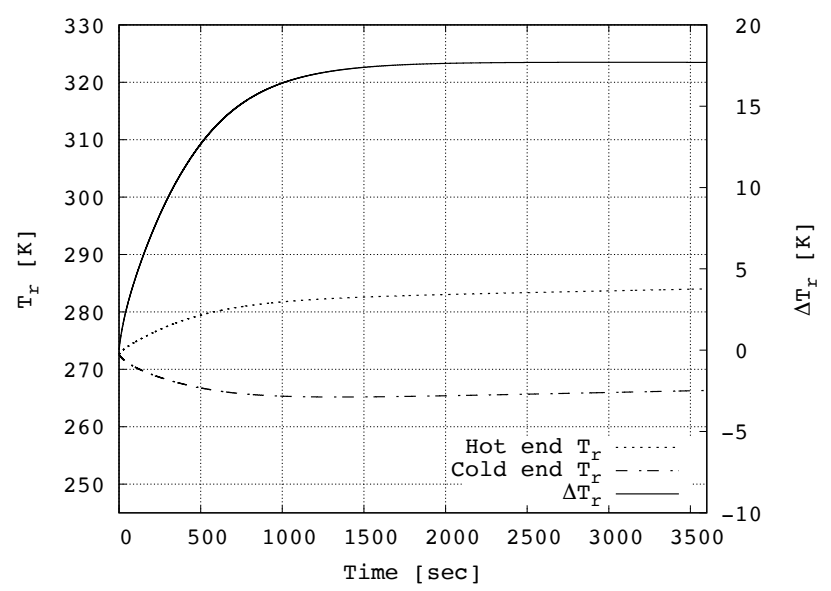

Fig. 8 Behavior of regenerator temperature at its both ends until steady state in the case of regenerator A.

は $\omega \tau$ と $\Delta T_{\mathrm{r}}$ との関係が定性的に表現できているといえる.

最後に蓄熱体流路断面積 $S_{\mathrm{r}}$ を変化させた際の蓄熱体両端の温度差 $\Delta T_{\mathrm{r}}$ の挙動を解析する．ただし，蓄熱体流路 水力直径 $D_{\mathrm{r}}$ は一定とし, 断面積のみを変化させる. 従って流路断面積の増加は蓄熱体流路本数を増加させること に対応する. 図 10 に流路断面積 $S_{\mathrm{r}}$ を変化させた場合の蓄熱体両端の温度差 $\Delta T_{\mathrm{r}}$ について, 断面開口率 $R_{\mathrm{OFA}}$ を用 いて解析したものを示す。図 10 より， $R_{\mathrm{OFA}}$ の増加に伴い $\Delta T_{\mathrm{r}}$ が増加する傾向が見られた。これは， $R_{\mathrm{OFA}}$ の増加 に伴い蓄熱体流路の肉厚は薄くなり, 熱音響現象によるヒートポンプ効果で輸送された熱を逆流させる蓄熱体内 の熱伝導が減少するため, 熱輸送効率が向上し $\Delta T_{\mathrm{r}}$ が増加したと考えられる.

\section{$3 \cdot 3$ 実験との比較に関する諸条件}

実験装置は表 1 の仕様に合わせて, 肉厚 $5 \mathrm{~mm}$ のアクリル管を用いて共鳴管とし，一方は閉端，他方はスピー 力を設置した．蓄熱体は表 2 に示す物性值を持つものを用い，その両端の温度は軸中心に $\mathrm{K}$ 型熱電対を設置して

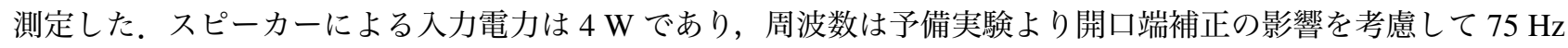
とした. 実験ではスピーカによる入力を一定として, 表 2 に示す 10 種類の蓄熱体に対して, 定常状態における蓄 熱体両端の温度差 $\Delta T_{\mathrm{r}}{ }^{(\exp )}$ の測定を 4 回実施した。

シミュレーションに用いる変数は, 実機を参考に定めた表 1 と表 2 ののとし, 各蓄熱体に対して, 作動流体 の流速振幅 $u_{\mathrm{amp}}$ は同じ值で数值計算を行う。ただし $u_{\mathrm{amp}}$ は, 蓄熱体 $\mathrm{A}$ の数值計算結果が実験結果と一致するよ うに推定した值を用いる。つまり蓄熱体 $\mathrm{A}$ に対して, 流速振幅 $u_{\mathrm{amp}}$ を変化させた際の定常状態（約 3600 秒）時 の蓄熱体両端の温度差 $\Delta T_{\mathrm{r}}$ を数值計算し, 実験值と一致する $u_{\mathrm{amp}}$ を探索し推定した. その結果, $u_{\mathrm{amp}}=2.65 \mathrm{~m} / \mathrm{s}$ で蓄熱体両端の温度差は実測值と $0.14 \%$ の誤差の範囲で一致したため, この值を用いて数值計算を行う. 


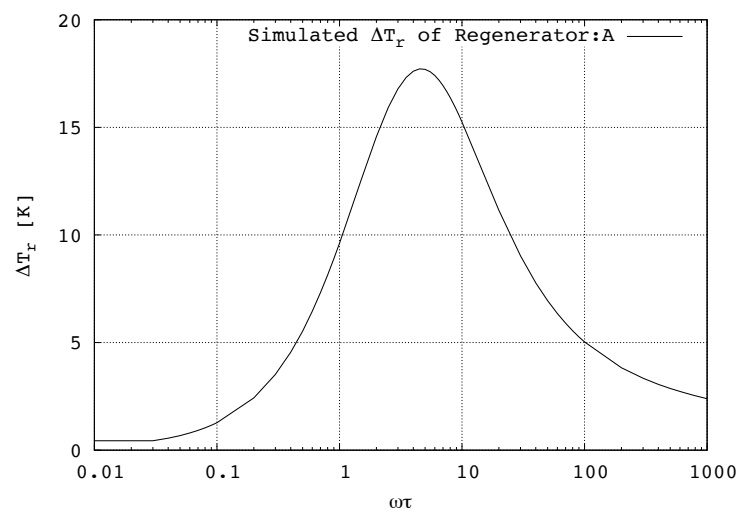

Fig. 9 Temperature difference between both ends of Fig. 10 regenerator $\Delta T_{\mathrm{r}}$ by changing $\omega \tau$ in the case of regenerator $\mathrm{A}$.

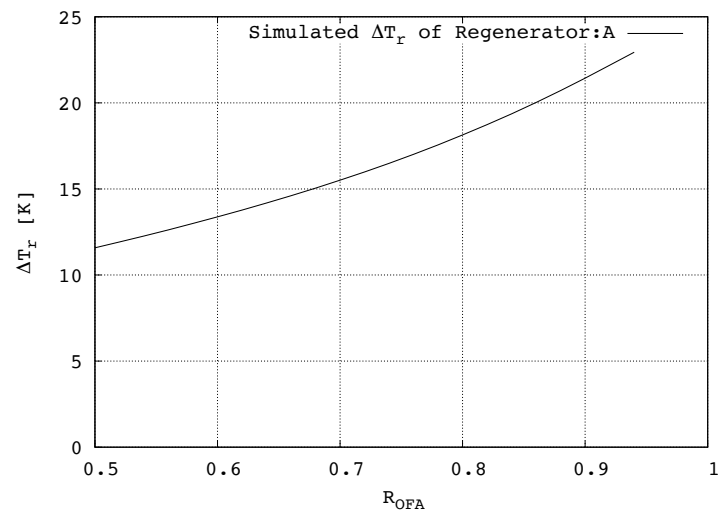

Temperature difference between both ends of regenerator $\Delta T_{\mathrm{r}}$ by changing $R_{\mathrm{OFA}}$ in the case of regenerator $\mathrm{A}$.

\section{$3 \cdot 4$ 実験結果との比較}

シミュレーション結果と実際の装置を動作させた結果を比較する．推定した流速振幅 $u_{\mathrm{amp}}$ を用いてシミュレー ションした結果 $\Delta T_{\mathrm{r}}{ }^{(\mathrm{sim})}$ と実測值 $\Delta T_{\mathrm{r}}{ }^{(\exp )}$ を $\omega \tau$ について解析したものを図 11 に, $R_{\mathrm{OFA}}$ について解析したものを 図 12 に示す。ただし図中の凡例は，表 2 の蓄熱体のサンプル ID を表しており，これらの蓄熱体の水力直径や流 路断面積は図中の実験結果の $\omega \tau, R_{\mathrm{OFA}}$ の範囲に相当している。 また，シミュレーション結果は蓄熱体 $\mathrm{A}$ の物性值 を代表して利用し, $\omega \tau$ と $R_{\mathrm{OFA}}$ を変化させたものである. さらに, 実測值 $\Delta T_{\mathrm{r}}{ }^{(\exp )}$ は 4 回の測定結果の平均値と し，そのエラーバーは測定值の最小と最大を信頼区間として表している.

図 9 より，実測值でも $\omega \tau \sim 5$ にて最も蓄熱体両端の温度差 $\Delta T_{\mathrm{r}}$ が大きく，そこから離れるとともに $\Delta T_{\mathrm{r}}$ が小さ くなるという性質が見られ，この性質はシミュレーション結果からも同様の傾向を確認することができた。 さら にこのシミュレーション結果は，代表して蓄熱体 A の物性值を利用して計算しているため，各蓄熱体について厳 密に実測值との比較はできないが，その場合でも多くの蓄熱体の $\Delta T_{\mathrm{r}}$ が良好に一致している． $R_{\mathrm{OFA}}$ は第 $3 \cdot 2$ 節に て，その值の増加に伴い熱音響現象によるヒートポンプ効果で輸送された熱を逆流させる蓄熱体内の熱伝導が減 少するため $\Delta T_{\mathrm{r}}$ が大きくなると考察していたが，図 10 より，実測值でも同様の傾向を確認できた．ただし蓄熱体 $\mathrm{C}$ はシミュレーション結果との乘離が約 33\% と最も大きいが，これは蓄熱体 $\mathrm{C}$ の熱伝導率が他のサンプルよりも $10 \%$ 以上高いため, $R_{\mathrm{OFA}}$ が大きくとも熱伝導の影響が軽減されにくく, 蓄熱体 $\mathrm{C}$ の両端温度差 $\Delta T_{\mathrm{r}}$ は, 蓄熱体 $\mathrm{A}$ の物性値を用いたシミュレーション結果よりも低く測定されたと考えられる。これらの結果より, 本論文の計算モ デルでは $\omega \tau$ と $R_{\mathrm{OFA}}$ に対して冷凍機の性能を予測する上で有効だといえる.

最後に，シミュレーション結果と実浿值を直接比較するために，それぞれの蓄熱体の物性值を用いて数值計算を 行う。各蓄熱体の物性值を用いた計算結果 $\Delta T_{\mathrm{r}}{ }^{(\mathrm{sim})}$ と実測值 $\Delta T_{\mathrm{r}}{ }^{(\exp )}$ を比較したものを図 13 に示す。ただし図 $13(\mathrm{~b})$ の縦軸は実測值に対する相対值 $\Delta T_{\mathrm{r}}{ }^{(\mathrm{sim})} / \Delta T_{\mathrm{r}}{ }^{(\mathrm{exp})}$ である。蓄熱体 $\mathrm{A}$ は $u_{\mathrm{amp}}$ の推定に用いていたため一致するのは 当然だが, それ以外の蓄熱体についても図 13 (b) より, 実験の測定誤差よりも $\Delta T_{\mathrm{r}}{ }^{(\operatorname{sim})}$ と $\Delta T_{\mathrm{r}}{ }^{(\exp )}$ の誤差のほうが 小さく，シミュレーションの結果は実測值に非常に近い值を示しているといえる.

本論文で示したシミュレーションの結果は，実際の装置の性質を非常によく表しており，冷凍機の性能評価をす る上で有用といえる結果が得られた。しかし, 動径方向の熱輸送については近似的なモデルを使用しているため, 蓄熱体と作動流体の動径方向の熱伝導や共鳴管の肉厚などが考慮できていない.これらに対応することで精度向 上が見込まれるが，二次元以上の計算モデルを用いると計算負荷が増えてしまう。そのため，性能への影響の高 い蓄熱体の挿入部分のみについて動径方向の熱輸送を考慮することで, 計算負荷を大きく増やすことなく，性能 予測の精度をさらに高めることを考えている.

\section{4. 結言}

本論文では熱音響冷凍機の性能予測のために，軸方向の作動流体の運動を準一次元でモデル化し，数值シミュ レーションを行った。その結果，一次元モデルにおいても熱音響現象によるヒートポンプ効果が再現されること が確認できた，さらに無次元量 $\omega \tau$ と $R_{\mathrm{OFA}}$ に対する蓄熱体両端の温度差 $\Delta T_{\mathrm{r}}$ の特性について，熱音響理論と同様 の傾向が見られた。また先行研究は計算負荷の高い二次元あるいは三次元モデルによるものが多く，一次元モデ 

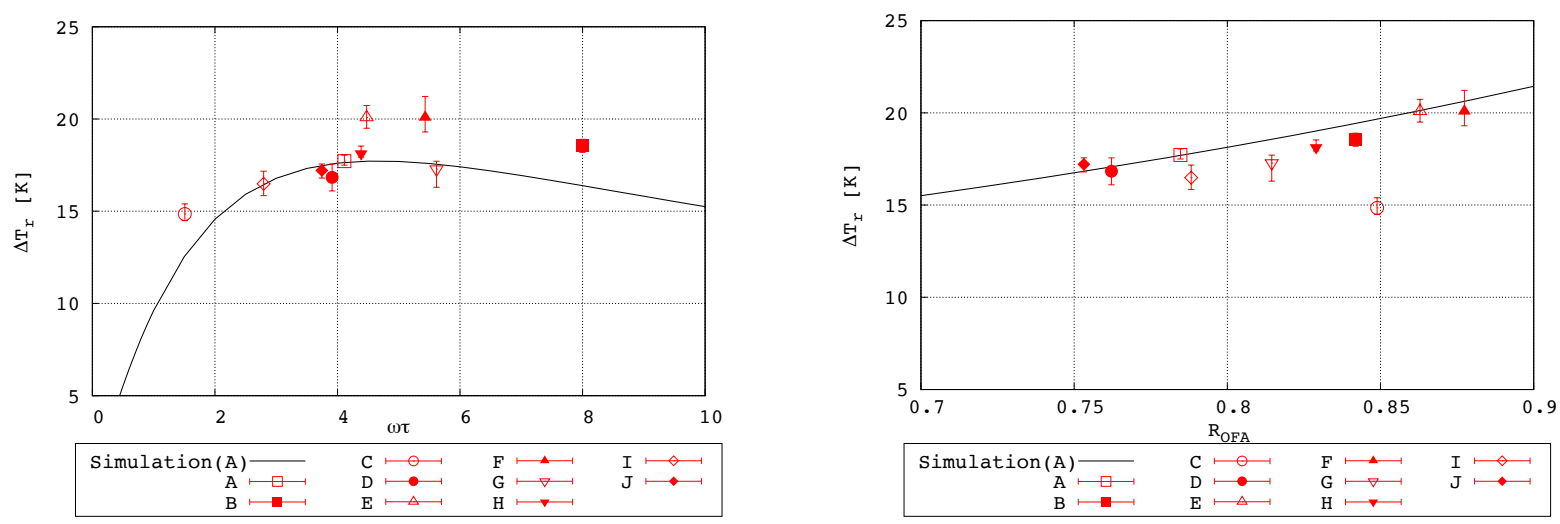

Fig. 11 Measured and Computed relations of $\Delta T_{\mathrm{r}}$ and Fig. 12 Measured and Computed relations of $\Delta T_{\mathrm{r}}$ and $\omega \tau$. The simulation is conducted by using the thermophysical property of regenerator A.

$R_{\text {OFA. }}$. The simulation is conducted by using the thermophysical property of regenerator A.

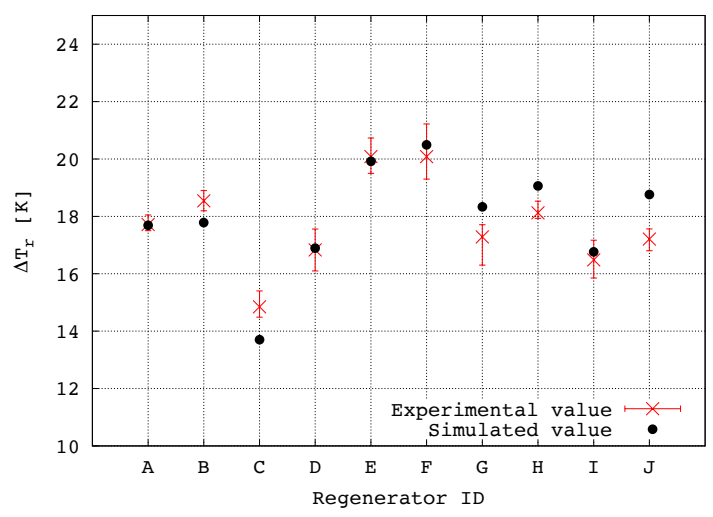

(a) Temperature difference $\Delta T_{\mathrm{r}}$

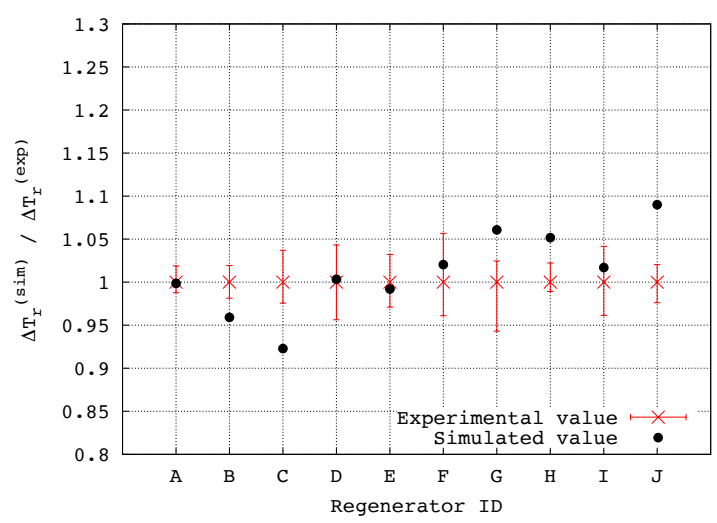

(b) Ratio of temperature difference $\Delta T_{\mathrm{r}}^{(\operatorname{sim})} / \Delta T_{\mathrm{r}}{ }^{(\exp )}$

Fig. 13 Comparison of measured temperature difference of regenerator $\Delta T_{\mathrm{r}}{ }^{(\exp )}$ and computed one $\Delta T_{\mathrm{r}}{ }^{(\operatorname{sim})}$.

ルについてはその計算結果の有効性について議論されているものは我々の知る限り存在しなかった。 そこで, シ ミュレーション結果を実際の装置を用いて実験した結果と比較し，検証を行ったそその結果，異なる物性值を持つ 10 個の蓄熱体に対して, 数值計算值 $\Delta T_{\mathrm{r}}{ }^{(\mathrm{sim})}$ は実測値 $\Delta T_{\mathrm{r}}{ }^{(\mathrm{exp})}$ と非常によく一致していた．以上より，一次元モデ ルのシミュレーションによって熱音響冷凍機の基本的特性を再現できることが確認できたといえる.

\section{文献}

De Jong, J. A., Wijnant, Y. H. and De Boer, A., Finite element simulation of a two-dimensional standing wave thermoacoustic engine, In Proceedings of Meetings on Acoustics ICA2013, Vol. 19, No. 1 (2013), p. 030002.

El-Rahman, A. I. A., Serry, M., Sedky, S. and Abdel-Rahman, E., Performance characterization of a micro-scale thermoacoustic energy harveester, 19th International Congress on Sound and Vibration (2012), pp. 1-9.

El-Rahman, A. I. A. and Abdel-Rahman, E., Computational fluid dynamics simulation of a thermoacoustic refrigerator, Journal of Thermophysics and Heat Transfer, Vol. 28, No. 1 (2013), pp. 78-86.

El-Rahman, A. I. A. and Abdel-Rahman, E., Characteristic-based non-linear simulation of large-scale standing-wave thermoacoustic engine, The Journal of the Acoustical Society of America, Vol. 136, No. 2 (2014), pp. 649-658.

藤原誠之, 田中誠一, 國峰寛司, 熱音響冷凍機の蓄熱体における熱伝達率の解析, 日本機械学会熱工学コンファレン 又講演論文集 (2012), pp. 25-26.

Gifford, W. E. and Longsworth, R. C., Pulse-tube refrigeration, Journal of Engineering for Industry, Vol. 86, No. 3 (1964), pp. 264-268.

Han, W., Liu, J., Chong, D. and Yan, J., One-dimensional numerical simulation of thermoacoustic engine with flux- 
corrected transport algorithm, International Communications in Heat and Mass Transfer, Vol. 39, No. 5 (2012), pp. 598-602.

Harten, A., On a class of high resolution total-variation-stable finite-difference schemes, SIAM Journal on Numerical Analysis, Vol. 21, No. 1 (1984), pp. 1-23.

Holzinger, T., Baumgartner, A. and Polifke, W., A quasi-one-dimensional model of thermoacoustics in the presence of mean flow, Journal of Sound and Vibration, Vol. 335 (2015), pp. 204-228.

Jaensch, S., Merk, M., Gopalakrishnan, E. A., Bomberg, S., Emmert, T., Sujith, R. I. and Polifke, W., Hybrid CFD/loworder modeling of nonlinear thermoacoustic oscillations, Proceedings of the Combustion Institute, Vol. 36, No. 3 (2017), pp. 3827-3834.

Kermani, M. and Plett, E., Modified entropy correction formula for the Roe scheme, In 39th Aerospace Sciences Meetingand Exhibit (2001), p. 83.

小清水孝夫, 久保田裕巳, 高田保之, 伊藤猛宏, ベーシック型パルス管冷凍機における熱流動数值解析, 日本機械学会 熱工学講演会講演論文集 (2002), pp. 369-370.

Merkli, P. and Thomann, H., Thermoacoustic effects in a resonance tube, Journal of Fluid Mechanics, Vol. 70, No. 1 (1975), pp. 161-177.

Mikulin, E. I., Tarasov, A. A. and Shkrebyonock, M. P., Low-temperature expansion pulse tubes, Advances in Cryogenic Engineering, Vol. 29 (1984), No. 629-637.

村上桂一, 藤原俊隆, 極超音速 TVD スキームにおけるエントロピー補正係数設定の効率化, 日本航空宇宙学会論文 集, Vol. 48, No. 554 (2000), pp. 61-66.

西谷富雄, パルス管冷凍機に関する最近の話題, 真空, Vol. 43, No. 4 (2000), pp. 477-483.

Rayleigh, J. W. S. B., The theory of sound, Vol. 2, Dover Publication (1896).

Skaria, M., Rasheed, K. A., Shafi, K. A., Kasthurirengan, S. and Behera, U., Simulation studies on the performance of thermoacoustic prime movers and refrigerator, Computers and Fluids, Vol. 111 (2015), pp. 127-136.

Sun, D., Wang, K., Guo, Y., Zhang, J., Xu, Y., Zou, J. and Zhang, X., CFD study on taconis thermoacoustic oscillation with cryogenic hydrogen as working gas, Cryogenics, Vol. 75 (2016), pp. 38-46.

日本熱物性学会編, 新編熱物性ハンドブック, 養賢堂 (2008).

富永昭, 波動冷凍の基礎, 低温工学, Vol. 25, No. 3 (1990), pp. 132-141.

上田祐樹, 琵琶哲志, 水谷宇一郎, 熱音響スターリング冷凍機, 低温工学/超電導学会講演概要集, Vol. 64 (2001), p. 30.

渡辺力夫, 藤井孝藏, 東野男, トンネル内圧縮波の一次元数值シミュレーション, 日本機械学会論文集 B 編, Vol. 61, No. 592 (1995), pp. 4379-4385.

矢崎太一, 上田祐樹, 琵琶哲志, 音を利用して冷やす方法 : 熱音響冷凍機の原理と試作, 日本音響学会誌, Vol. 62, No. 2 (2006), pp. 128-133.

Yee, H. C., Upwind and symmetric shock-capturing schemes, NASA Technical Memorandum, No. 89464 (1987).

Zhu, S., Peiyi, W. and Zhongqi, C., Double inlet pulse tube refrigerators: an important improvement, Cryogenics, Vol. 30, No. 6 (1990), pp. 514-520.

\section{References}

De Jong, J. A., Wijnant, Y. H. and De Boer, A., Finite element simulation of a two-dimensional standing wave thermoacoustic engine, In Proceedings of Meetings on Acoustics ICA2013, Vol. 19, No. 1 (2013), p. 030002.

El-Rahman, A. I. A., Serry, M., Sedky, S. and Abdel-Rahman, E., Performance characterization of a micro-scale thermoacoustic energy harveester, 19th International Congress on Sound and Vibration (2012), pp. 1-9.

El-Rahman, A. I. A. and Abdel-Rahman, E., Computational fluid dynamics simulation of a thermoacoustic refrigerator, Journal of Thermophysics and Heat Transfer, Vol. 28, No. 1 (2013), pp. 78-86.

El-Rahman, A. I. A. and Abdel-Rahman, E., Characteristic-based non-linear simulation of large-scale standing-wave thermoacoustic engine, The Journal of the Acoustical Society of America, Vol. 136, No. 2 (2014), pp. 649-658.

Fujiwara, S., Tanaka, S. and Kunimime, K., Numerical analysis of heat transfer coefficient at the regenerator or thermoacoustic refrigerator, Proceedings of Thermal Engineering Conference (2012), pp. 25-26 (in Japanese). 
Gifford, W. E. and Longsworth, R. C., Pulse-tube refrigeration, Journal of Engineering for Industry, Vol. 86, No. 3 (1964), pp. 264-268.

Han, W., Liu, J., Chong, D. and Yan, J., One-dimensional numerical simulation of thermoacoustic engine with fluxcorrected transport algorithm, International Communications in Heat and Mass Transfer, Vol. 39, No. 5 (2012), pp. 598-602.

Harten, A., On a class of high resolution total-variation-stable finite-difference schemes, SIAM Journal on Numerical Analysis, Vol. 21, No. 1 (1984), pp. 1-23.

Holzinger, T., Baumgartner, A. and Polifke, W., A quasi-one-dimensional model of thermoacoustics in the presence of mean flow, Journal of Sound and Vibration, Vol. 335 (2015), pp. 204-228.

Jaensch, S., Merk, M., Gopalakrishnan, E. A., Bomberg, S., Emmert, T., Sujith, R. I. and Polifke, W., Hybrid CFD/loworder modeling of nonlinear thermoacoustic oscillations, Proceedings of the Combustion Institute, Vol. 36, No. 3 (2017), pp. 3827-3834.

Kermani, M. and Plett, E., Modified entropy correction formula for the Roe scheme, In 39th Aerospace Sciences Meetingand Exhibit (2001), p. 83.

Koshimizu, T., Kubota, H., Takata, Y. and Ito, T., Numerical analysis of heat and fluid flow in a basic pulse-tube refrigerator: analysis on heat exchange between the tube wall and the working gas, Proceedings of Thermal Engineering Conference (2002), pp. 369-370 (in Japanese).

Merkli, P. and Thomann, H., Thermoacoustic effects in a resonance tube, Journal of Fluid Mechanics, Vol. 70, No. 1 (1975), pp. 161-177.

Mikulin, E. I., Tarasov, A. A. and Shkrebyonock, M. P., Low-temperature expansion pulse tubes, Advances in Cryogenic Engineering, Vol. 29 (1984), No. 629-637.

Murakami, K. and Fujiwara, T., Improvement in entropy correction parameter of TVD scheme for a hypersonic flow: comparison with existing flight data and other CFD methods, Transactions of Journal of the Japan Society for Aeronautical and Space Sciences, Vol. 48, No. 554 (2000), pp. 61-66 (in Japanese).

Nishitani, T., Recent topics of the pulse tube refrigerator, Shinku, Vol. 43, No. 4 (2000), pp. 477-483 (in Japanese).

Rayleigh, J. W. S. B., The theory of sound, Vol. 2, Dover Publication (1896).

Skaria, M., Rasheed, K. A., Shafi, K. A., Kasthurirengan, S. and Behera, U., Simulation studies on the performance of thermoacoustic prime movers and refrigerator, Computers and Fluids, Vol. 111 (2015), pp. 127-136.

Sun, D., Wang, K., Guo, Y., Zhang, J., Xu, Y., Zou, J. and Zhang, X., CFD study on taconis thermoacoustic oscillation with cryogenic hydrogen as working gas, Cryogenics, Vol. 75 (2016), pp. 38-46.

The Japan Society of Thermophysical Properties ed., Thermophysical properties handbook, Yokendo (2008) (in Japanese).

Tominaga, A., Thermoacoustic refrigerations, Journal of the Cryogenic Society of Japan, Vol. 25, No. 3 (1990), pp. 132-141 (in Japanese).

Ueda, Y., Biwa, T. and Mizutani, U., A thermoacoustic strling cooler, Meetings of Cryogenics and Superconductivity, Vol. 64 (2001), p. 30 (in Japanese).

Watanabe, R., Fujii, K. and Higashino, F., One-dimensional numerical simulation of a compression wave induced by a train entering a tunnel, Transactions of the Japan Society of Mechanical Engineers, Series B, Vol. 61, No. 592 (1995), pp. 4379-4385 (in Japanese).

Yazaki, T., Ueda, Y. and Biwa, T., Cooling by sound: understanding of thermo-acoustic refrigerator, The Journal of the Acoustical Society of Japan, Vol. 62, No. 2 (2006), pp. 128-133 (in Japanese).

Yee, H. C., Upwind and symmetric shock-capturing schemes, NASA Technical Memorandum, No. 89464 (1987).

Zhu, S., Peiyi, W. and Zhongqi, C., Double inlet pulse tube refrigerators: an important improvement, Cryogenics, Vol. 30, No. 6 (1990), pp. 514-520. 